\title{
Research on Accurate Identification of Tourism Poverty Alleviation Based on Industrial Chain Perspective
}

\author{
Wu Bing \\ School of Geography and Tourism, Shaanxi Normal University, Xi’an 710119, China
}

Keywords: poverty alleviation and construction; accurate identification; tourism industry chain; tourism poverty alleviation

\begin{abstract}
As the tourism industry matures, it plays an increasingly significant role in promoting regional economic development and increasing employment opportunities. Therefore, it has also become an important way for the country to help the poor. However, in many areas, the poor population has not been the biggest beneficiary because of the limited management level of tourism. In order to solve the problem of high accuracy of tourism poverty alleviation, is proposed in this paper from the perspective of the tourism industry chain as the starting point, from the tourism poverty alleviation of recognition and recognition of the project, the construction of tourism poverty alleviation precise recognition system, has a certain reference value for the precision of the promotion of tourism poverty alleviation work.
\end{abstract}

\section{Preface}

The most difficult task of building a well-off society in an all-round way is to ensure the poverty alleviation in rural areas by 2020. By 2015, there were still about 55000000 poor people in China. Many of the poor people were in areas where tourism resources were relatively rich, but tourism market development was not developed. For these areas, speeding up the accurate poverty alleviation of tourism is an important way to eliminate the absolute poverty and win the fight against poverty. Rural tourism poverty alleviation is a kind of developing means of poverty alleviation for poor areas or underdeveloped areas, taking the poverty population as the main beneficiary, and by using existing local mining development value of various kinds of potential "local" resources for the development of tourism industry, using the method of tourism poverty alleviation precise identification, a development oriented poverty alleviation means of promoting the development of local economy, in order to promote economic, social and ecological development of the poor areas.

\section{The perspective of tourism industry chain}

The tourism industry chain is for the harmonious development of local economy and ecological environment, and the process of providing products and services to consumers from tourism enterprises to consumers. There are great differences between tourism industry and general merchandise industry chain: the former has the characteristics of non mobility, usually tourists move towards the direction of tourism products, while the latter move from origin to consumer groups. The large span of tourism products usually requires the coordination between multiple sectors and industries. Therefore, it has multiple directions and comprehensiveness, while the general merchandise is a single production mode, which is made up of raw materials, semi-finished products, finished products and consumer groups. Diversity in the tourism industry chain is mainly manifested in two aspects: one is longitudinal process of tourists from the residence to the tourism consumption; two is the transverse process in the tourism tourists to catering, accommodation, transportation, travel, purchase, leisure and entertainment landscape six aspects of demand. The framework of the tourism industry chain is shown in Figure 1. 


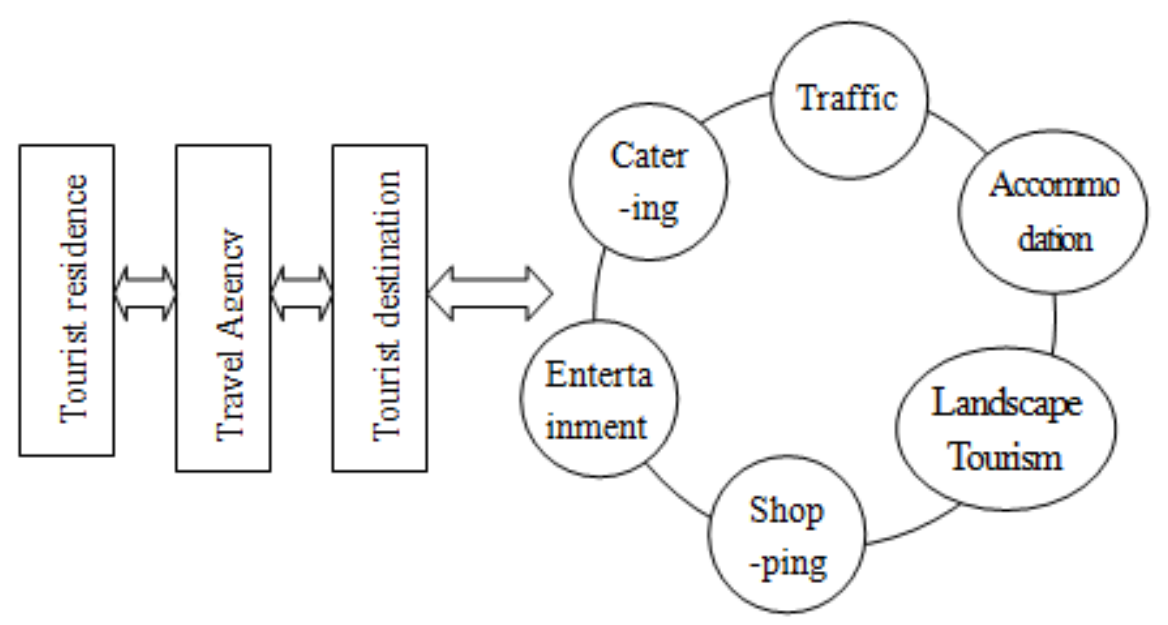

Fig.1 The framework map of the tourism industry chain system

In the traditional manufacturing industry, a company with the most advanced and most advanced technology is the core of the whole industry chain that in the industry, and also is the most profitable enterprise in the industry, for example, the manufacturing enterprise of mobile phone producing microprocessors. But the expert on tourism industry core view of tourism industry chain can be quite different, some scholars believe that the travel agency is the core of the whole industry, the main reason is that the company holding the vast majority of passengers; some scholars believe that the tourism destination is the core of the whole industry, because this place is good or bad directly determines the scenery the number of tourists to tourism; some scholars believe that the tourism experience is the core of the whole industry. The author in this paper believes that the tourism industry chain is more complex and special, and there is a certain competitive relationship between travel agencies and tourist attractions in the tourism chain. Therefore, the competition advantage in the market is strong, most visitors are attracted, this scenic spot is the core of the whole industry chain; but in the developed economy, popular travel city, tourism base, the travel agency can choose tourist attractions, especially those of high visibility or open new tourist attractions, it mainly depends on the travel agency publicity, so tourism is the core of the whole industry chain.

\section{Accurate identification of tourism poverty alleviation}

Tourism is the use of human resources and pleasant scenery resources rich in poor areas, the development of tourism resources, the tourism form contains a travel, insurance, security, accommodation, stores and tour guide as one of the industrial chain, increase the income of local residents and government tax, led the people out of poverty. Different from the "blood transfusion" form of poverty alleviation, tourism poverty alleviation is a new "hematopoiesis" type of poverty alleviation. The "blood transfusion" type of poverty alleviation is to carefully distinguish the poor people, and the "hematopoiesis" type of poverty alleviation is to identify the feasibility and profitability of the tourism project.

\subsection{Identification of the poor and poverty alleviation by tourism.}

Poverty alleviation is the maximum protection of the legitimate rights and interests of the poor, and alleviating or eliminating the economic burden of the poor. The target population for tourism poverty alleviation is a real poor population, and the identification process for the poor and poor tourists is shown in Figure 2. 


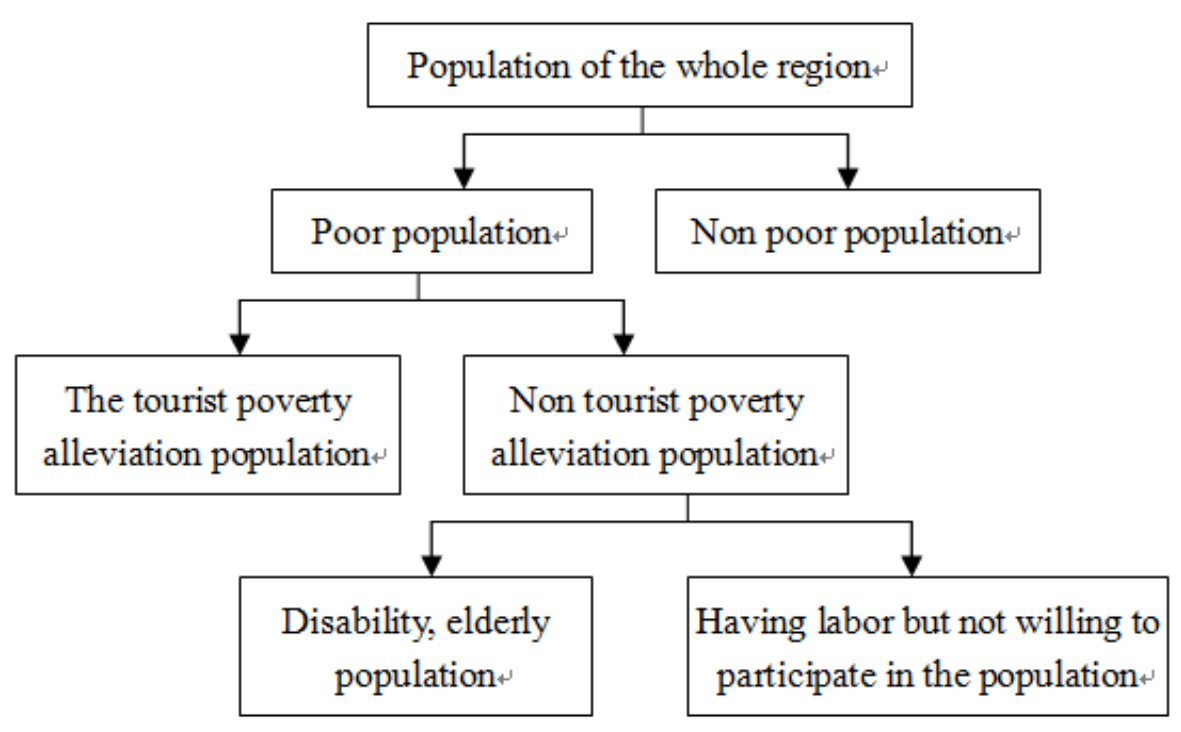

Fig.2 The identification process for poverty alleviation and poverty alleviation

As shown in Figure 2, in recognition of the poor target, first of all, the need to distinguish between poverty and non poverty population; secondly, through further investigation and assessment, will be able to distinguish between poor and not through the tourism industry to support the support by the method of poverty; and then the non poor population of tourism for the disabled, elderly population poverty alleviation of the poverty population and labor have but not willing to participate in the. In the whole population, the object of tourism poverty alleviation is those who have the ability to work and are willing to develop their own tourism resources to improve their own economic resources. These people generally do not have the knowledge and skills or economic support of tourism development, and there are some obstacles to participate in tourism development. The whole process of tourism poverty alleviation, training is the lack of tourism development in the knowledge and skills of the people, solve their lack of low quality, it is difficult to enter the market and weak knowledge and skills of defects, lack of physical capital to carry out credit work, reduce the poverty population tourism participation in Tourism development obstacles, to help them in tourism development division a cup of soup, improve their living conditions.

\subsection{Identification of tourism poverty alleviation projects.}

Poor areas generally have better natural environment and have certain tourism development conditions, but not for tourism development. Therefore, a feasible project is very important. Tourism poverty alleviation projects support the poor population and tourism development. The accuracy of tourism poverty alleviation projects directly determines the competitiveness, impact and return rate of tourism development in poor areas. A feasible and benefit in tourism poverty alleviation projects must have four conditions: (1) The scientific development plan has higher, (2) There are high match between the project and the tourism development in the poor areas, which can avoid gaps between actual situation and poverty-stricken areas, (3) The project has certain diversity, (4) The project can meet the market demand, to attract tourists, get greater benefits.

As an emerging industry, the tourism development project is a market economy behavior, must comply with the laws of the market from the project, choose to rely on the local environment and human resources, combined with market demand, correctly handle the relationship between government and market, and improve the effectiveness of the implementation of the project, at the same time should also examine the surrounding tourism projects, to ensure that the difference of tourism products the development, to avoid the homogenization of competition. In addition, tourism poverty alleviation projects should pay attention to the opportunities and benefits of the development of the poor, and bring them rich benefits. Tourism poverty alleviation can only bring net income to poor individuals or groups, which is conducive to the development of poor people, and can be called tourism poverty alleviation project. 


\subsection{Tourism poverty alleviation program based on Industrial Chain Perspective}

From the perspective of tourism industry chain, this paper determines the core of the tourism industry chain according to the target area environment and humanities characteristics. With the help of government departments, we will identify the poverty alleviation projects in the participation of villagers according to the polls. The main way of tourism poverty alleviation is innovation. In addition, there are three ways to implement poverty alleviation, poverty alleviation and intellectual poverty alleviation.

\subsubsection{Fund poverty alleviation}

With the help of the poverty alleviation fund, the poverty alleviation intensity of tourism development areas is increased. In the process of building the poverty alleviation area, it is necessary to start a project first. With this fund, a number of pilot projects can be built. It is very important for the subsidized area to improve the strength of the tourism poverty alleviation fund. We should provide key and continuous financial support for the project with high project value and good market development prospects, so as to achieve the goal of building the project, namely, the goal of opening up and opening up.

\subsubsection{Advocacy of poverty alleviation}

Propaganda and poverty alleviation is the source of tourism poverty alleviation projects. Therefore, marketing system construction is also a key point in the whole project, which directly determines the success or failure of the whole development project. In the course of the construction of the marketing system, we should strengthen the publicity guidance and plan design for the tourism poverty alleviation area. In addition, we should expand propaganda efforts in Beijing Tianjin Tangshan, Yangtze River Delta and Pearl River Delta, and extract tourists from these cities with large tourism trips to strengthen the breadth and depth of tourism marketing.

\subsubsection{Education and poverty alleviation}

In most poverty-stricken areas, its educational resources are scarce, and the effect of education is not satisfactory. The tourism education resources in these areas can not meet the development of tourism poverty alleviation projects. Therefore, the tourism education and training as the focus of development, can set up the computer room in these areas, use the network teaching mode, the tourism administrative personnel, tourism enterprises, tourism service personnel management, tourism education and training of teachers training staff of the four groups, experts and scholars famous for learners etc.uncertainty, improve tourism service and management level. The education and Training Fund for tourism poverty alleviation area should be established, and the source of funds for education and training should be solved by the way of business co-ordination and government subsidy, so as to speed up the speed and quality of regional tourism poverty alleviation.

\section{Conclusion}

In this paper, from the perspective of tourism industry chain as a starting point, with the harmonious development of the local economy and the ecological environment, to determine the core tourism industry chain to the target area, "with a" bottom-up "approach, from the tourism poverty alleviation of recognition and recognition of the project, the construction of tourism poverty alleviation precise identification system, and determine the implementation plan for the support of the tourism to fund poverty alleviation, poverty alleviation funds and intellectual poverty in three ways, the development of tourism poverty alleviation projects, strengthen the construction of the industrial chain, improve the tourism efficiency and realize the goal of tourism poverty alleviation, has a certain significance.

\section{Acknowledgements}

The work was supported by Shaanxi Social Science Fund Project with the project number 
2016R011 and the project name Research on the innovation model of rural tourism in Qinba mountain area of Shaanxi Province.

\section{References}

[1] Xing Huibin, Xi Jianchao. Yanshan - Taihang Mountain area tourism Jian Chao. The precise poverty alleviation mode innovation research [J]. Journal of Hebei University (Philosophy and Social Science),Vol.42 (02), (2017), p.118-125.

[2] Lu Jiao, Fang Shiming. Tourism poverty alleviation precise system research -- Taking Guangdong Mount Danxia as an example of Xia Fu Cun [J]. Hubei Agricultural Sciences, Vol.56 (02),(2017), p.360-364369.

[3] Chen Xiaoning, Guo Jin, Li Junsong, Liu Rui. Based on large data based tourism precision poverty alleviation information system design and research [J]. Technology Outlook, Vol.26(36), (2016), p.7.

[4] Zhang Le. The basic theory of tourism precision Poverty Alleviation under the backdrop of supply reform, [J]. Economic \& Trade Update, Vol.34,( 2016), p.36-38.

[5] Yang Na. The relevant concepts and relations of tourism precision poverty alleviation [J]. Rural Economy and Science-Technology, Vol.27 (16), (2016), p.71,73.

[6] Wang Shanyu, Li Cunfa. Underdeveloped areas of poverty must firmly grasp the "precision" does not relax -- a case study of Heze city [J]. New West, Vol.14, (2016), p. 51-52.

[7] Chen Qiuhua, Ji Jinxiong. Research on the path of precision poverty alleviation for rural tourism [J]. Fujian Tribune (The Humanities \& Social Sciences), No.05, (2016), p. 196-200.

[8] Ma Binbin, Lu Xiaobo. Study on rural tourism of Haitang Mountain based on the accurate poverty alleviation perspective [J]. Liaoning Agricultural Science, No.02, (2016), p.30-34.

[9] Zhang Wei. Effect analysis and Optimization Research of tourism poverty alleviation development in scenic area [D]. Anhwei Normal University, (2005).

[10] Hong Yeying. Precise tourism poverty alleviation theory and practice take Fuling district as an example, [J]. Laodong Baozhang Shijie, Vol. 14, (2015), p. 42-43..

[11] Deng Xiaohai, Zeng Liang, Luo Mingyi. Accurate identification of tourism Poverty Alleviation under the background of accurate poverty alleviation and Research on [J]. Ecological Economy, Vol.31 (04), (2015), p. 94-98.

[12] Deng Xiaohai, Zeng Liang. Based on the mechanism design theory, China's tourism poverty alleviation mechanism is adapted to [J]. Contemporary Economy \& Management, Vol.37(02), (2015), p. 73-77.

[13] Deng Xiaohai, Zeng Liang, Luo Mingyi. Study on the diagnosis and Countermeasures of tourism Poverty Alleviation under the view of industrial chain [J]. Contemporary Economy \& Management, Vol.36 (11), (2014), p. 56-59.

[14] Chen Youhua. A new train of thought for the transformation and upgrading of China's tourism poverty alleviation model [J]. Resource Development \& Market, Vol.30 (06), (2014), p. 717-721.

[15] Zhou Jiang. Research on the development of tourism industry cluster of resource based tourism [D]. Lanzhou University, (2011).

[16] Wang Yu, Wu Dianting. Based on the perspective of the tourism industry chain, traditional handicraft development countermeasures [J]. Inquiry Into Economic Issues, No.04, (2011), p. 168-172. 